\title{
Exploration of Electrochemical Intermediates of the Anticancer Drug Doxorubicin Hydrochloride Using Cyclic Voltammetry and Simulation Studies with an Evaluation for Its Interaction with DNA
}

\author{
Partha Sarathi Guin ${ }^{1}$ and Saurabh Das ${ }^{2}$ \\ ${ }^{1}$ Department of Chemistry, Shibpur Dinobundhoo Institution (College), 412/1 G. T. Road (South), Howrah 711102, India \\ ${ }^{2}$ Department of Chemistry, Jadavpur University, Raja SC Mullick Road, Kolkata 700032, India
}

Correspondence should be addressed to Partha Sarathi Guin; parthasg@gmail.com

Received 16 June 2014; Accepted 5 July 2014; Published 3 August 2014

Academic Editor: Shengshui $\mathrm{Hu}$

Copyright (C) 2014 P. S. Guin and S. Das. This is an open access article distributed under the Creative Commons Attribution License, which permits unrestricted use, distribution, and reproduction in any medium, provided the original work is properly cited.

Electrochemical behavior of the anticancer drug doxorubicin hydrochloride was studied using cyclic voltammetry in aqueous medium using Hepes buffer ( $\mathrm{pH} 7.4$ ). At this $\mathrm{pH}$, doxorubicin hydrochloride undergoes a reversible two-electron reduction with $E_{1 / 2}$ value $-665 \pm 5 \mathrm{mV}$ (versus $\mathrm{Ag} / \mathrm{AgCl}$, saturated $\mathrm{KCl}$ ). Depending on scan rates, processes were either quasireversible (at low scan rates) or near perfect reversible (at high scan rates). This difference in behavior of doxorubicin hydrochloride with scan rate studied over the same potential range speaks of differences in electron transfer processes in doxorubicin hydrochloride. Attempt was made to identify and understand the species involved using simulation. The information obtained was used to study the interaction of doxorubicin hydrochloride with calf thymus DNA. Cathodic peak current gradually decreased as more calf thymus DNA was added. The decrease in cathodic peak current was used to estimate the interaction of the drug with calf thymus DNA. Nonlinear curve fit analysis was applied to evaluate the intrinsic binding constant and site size of interaction that was compared with previous results on doxorubicin hydrochloride-DNA interaction monitored by cyclic voltammetry or spectroscopic techniques.

\section{Introduction}

Anthracycline anticancer drugs are amongst the most active agents in oncology $[1,2]$, first recognized for their antibacterial properties in 1939. Their chemical characterization led to an increase in use after therapeutic value of their antineoplastic activity was described in the early 1960s. Two anthracyclines, daunomycin (daunorubicin) and doxorubicin hydrochloride (hydroxyl daunomycin or doxorubicin), were initially isolated from Streptomyces peucetius var. caesitue $[3,4]$ and exhibit the widest spectrum of antitumor activity $[5,6]$. The presence of a side chain primary alcohol group in doxorubicin hydrochloride has important consequences in antitumor activity that makes it more valuable than other anthracyclines. Doxorubicin hydrochloride is used in the treatment of breast cancer, childhood solid tumors, soft tissue sarcomas, and aggressive lymphomas.
However, its use is often hampered by cumulative doselimiting cardiotoxicity resulting in cardiomyopathy and congestive heart failure that may be irreversible [7].

Though there is still some controversy with regard to their mode of action, anticancer activity or cytotoxic effects involve interaction with nuclear components, especially DNA and type-II topoisomerase $[8,9]$. The anthracyclines contain a planar aglycone ring coupled with an aminosugar. The planar anthraquinone intercalates between base pairs of DNA by $\pi-\pi$ stacking and hydrophobic interaction. Its long axis is nearly perpendicular to the axis of the double helix. The aminosugar interacts with negatively charged phosphate groups in the DNA major groove $[10,11]$. In addition to stacking and hydrophobic interaction, intercalation is further stabilized by hydrogen bonding between the bases of DNA and the drug molecule $[12,13]$. In case of daunomycin the single positive charge contributes electrostatically to binding 
[12]. Intercalation causes a change in the shape of the DNA double helix, thereby hindering DNA replication and RNA transcription $[12,14,15]$. Doxorubicin hydrochloride and daunomycin were observed to accumulate rapidly in living cells in the nuclei and bind to chromosomal DNA $[16,17]$. In the cell, nuclear DNA is associated with a variety of proteins forming a nucleoprotein complex called chromatin [18]. Accumulating evidence suggests these drugs interact with chromatin leading to chromatin unfolding and aggregation that causes a change in structure and function of chromatin $[19,20]$. The structural disruption is likely to interfere with metabolic processes of DNA (replication and transcription) contributing to apoptosis induced by these drugs in cancer cells $[19,20]$.

In addition, inside the cell, anthracyclines react with cytochrome reductase in the presence of reduced nicotinamide adenine dinucleotide phosphate (NADPH) to form semiquinone radical intermediates which participate in oxidation-reduction reactions generating superoxide radical anion $\left(\mathrm{O}_{2}{ }^{--}\right)$that are converted to hydrogen peroxide $\left(\mathrm{H}_{2} \mathrm{O}_{2}\right)$ and hydroxyl radical $\left(\mathrm{OH}^{*}\right)[21,22]$. The free radicals induce membrane-lipid peroxidation, DNA strand scission, and direct oxidation of purine-pyrimidine bases, thiols, and amines and also contribute to cardiotoxicity. The heart tissue being devoid of glutathione peroxidase is unable to convert superoxide radicals to oxygen and is therefore handicapped in this regard $[23,24]$. Therefore the study of the redox behavior of anthracyclines is an important aspect as it helps in the understanding of toxicities and therapeutic efficiencies. There are many reports on the redox behavior of these drugs correlated with biological findings $[25,26]$. The present study is an attempt to revisit the redox behavior of doxorubicin hydrochloride in aqueous media at physiological $\mathrm{pH}$ (7.4) using cyclic voltammetry trying to understand the mechanism by which the molecule copes with reduction.

\section{Materials and Methods}

Doxorubicin hydrochloride [98.0-100.0\% (HPLC)] was purchased from Sigma-Aldrich, USA, and it was used without any purification. Since the quinone moiety is sensitive to light, solutions were prepared just before experiment and kept in the dark. CT DNA was purchased from Sisco Research Laboratory, India. After dissolution of CT DNA in buffer, purity was checked from absorbance ratio $A_{260} / A_{280}$. For all solutions, this ratio was in the range $1.8<\mathrm{A}_{260} / \mathrm{A}_{280}>1.9$ and provided a good estimate of purity [27]. DNA obtained from biological sources has proteins as contaminants that absorb more heavily around $280 \mathrm{~nm}$, owing to tryptophan with some contribution from tyrosine residues that decrease $A_{260} / A_{280}$ ratio. An $\mathrm{A}_{260} / \mathrm{A}_{280}$ ratio of 1.8-1.9 is considered "clean" with regard to DNA purity indicating that no further deproteinization is required [27]. Concentration of DNA (in bases) was determined taking $\epsilon_{260}=6600 \mathrm{M}^{-1} \mathrm{~cm}^{-1}$ for CT DNA. Analytical grade Hepes buffer (N-2-hydroxyethylpiperazineN-2-ethane-sulphonic acid, $10 \mathrm{mM}$ ) (Spectrochem Pvt. Ltd., India) was used to maintain a $\mathrm{pH}$ of $\sim 7.4$ in all experiments. Sodium chloride (AR grade) obtained from Merck, Germany, was used to maintain ionic strength. It was also used as the supporting electrolyte for electrochemical experiments. All solutions were prepared in triple distilled water. Cyclic voltammetry experiments were done using the conventional three-electrode system at $25^{\circ} \mathrm{C}$. A glassy carbon electrode of surface area $0.1256 \mathrm{~cm}^{2}$ was the working electrode, while platinum wire and $\mathrm{Ag} / \mathrm{AgCl}$, saturated $\mathrm{KCl}$, were used as the counter and reference electrode, respectively. Experiments were carried out using EG \& $G$ Potentiostat Model 263A. Voltammetric experiments on doxorubicin hydrochloride were done in aqueous buffer $(\mathrm{pH} 7.4)$ in the presence and absence of CT DNA. All experimental solutions were degassed for $30 \mathrm{~min}$ with high-purity argon before cyclic voltammetry was done. Microprocessor $\mathrm{pH} / \mathrm{ION}$ meter (pMX 3000) was used for recording $\mathrm{pH}$ of solutions. UV-Vis spectroscopic studies were carried out using a spectrophotometer (model UNICAM UV 500). A pair of $10 \times 10 \mathrm{~mm}$ path length quartz cuvettes was used. Simulation of electrochemical data was done to explain the probable mechanism for the reactions using esp24b software developed by Dr. Carlo Nervi [28]. Simulation was carried out in planar geometry and cathodic currents were taken positive.

\section{Results and Discussion}

3.1. Electrochemical Reduction of Doxorubicin Hydrochloride. In $15 \mathrm{mM}$ Hepes buffer ( $\mathrm{pH} 7.4$ ) containing $160 \mathrm{mM} \mathrm{NaCl}$, doxorubicin hydrochloride $(33 \mu \mathrm{M})$ undergoes two-electron reversible reduction generating a cathodic peak at $-690 \pm$ $5 \mathrm{mV}$ (versus $\mathrm{Ag} / \mathrm{AgCl}$, saturated $\mathrm{KCl}$ ) with the corresponding anodic peak at $-640 \pm 5 \mathrm{mV}$ (versus $\mathrm{Ag} / \mathrm{AgCl}$, saturated $\mathrm{KCl}$ ) (Figure 1) at a scan rate of $100 \mathrm{mVs}^{-1}$. The formal reduction potential $\left(E_{1 / 2}\right)$ was $-665 \pm 5 \mathrm{mV}$ (versus $\mathrm{Ag} / \mathrm{AgCl}$, saturated $\mathrm{KCl}$ ). The variation of peak potentials with scan rate is shown in Figure 2 and the corresponding electrochemical parameters are summarized in Table 1. In Figure 2 the cyclic voltammograms were taken in the potential range 0 to $-0.85 \mathrm{~V}$, since beyond $-0.85 \mathrm{~V}$ there is no reduction or oxidation under the experimental condition, which is clear from Figure 1. Previous studies [29, 30] showed that, at acidic $\mathrm{pH}$ and neutral $\mathrm{pH}$, there were two reduction peaks, one reversible two-electron reduction of the quinone unit of doxorubicin hydrochloride to quinone dianion species at $-600 \mathrm{mV}$ (versus calomel electrode), that is, $-644 \mathrm{mV}$ (versus $\mathrm{Ag} / \mathrm{AgCl}$, saturated $\mathrm{KCl}$ ), and another irreversible peak at much more negative potential owing to hydrogen evolution [31]. However, the second irreversible reduction peak vanished at alkaline $\mathrm{pH}[31,32]$. Since the present study was carried out at $\mathrm{pH} 7.4$, that is, slightly alkaline, the second cathodic peak was not observed at more negative potential which was in accordance with previous results $[31,32]$. A plot of the ratio of the anodic to cathodic peak current $\left(I_{\mathrm{pa}} / I_{\mathrm{pc}}\right)$ versus the logarithm of scan rate (log $\left.v\right)$ (Figure 3) shows that the $I_{\mathrm{pa}} / I_{\mathrm{pc}}$ ratio is less than unity in case of lower scan rate, while at higher scan rate it is almost unity [32]. This suggests that the reduction of doxorubicin hydrochloride at physiological $\mathrm{pH}$ at lower scan rates was quasireversible, while at higher scan rate it was almost reversible. Using these observations for low and high scan rates a simulation study was performed to understand 
TABLE 1: Variation of peak potentials and formal reduction potential with scan rate for the reduction of doxorubicin hydrochloride in aqueous buffer at pH 7.4 on glassy carbon electrode. [Doxorubicin hydrochloride] $=33 \mu \mathrm{M}$, [Hepes buffer] $=15 \mathrm{mM}$, and $[\mathrm{NaCl}]=160 \mathrm{mM}$ and temperature $=25^{\circ} \mathrm{C}$.

\begin{tabular}{lccc}
\hline Scan rate $\left(\mathrm{mVs}^{-1}\right)$ & Cathodic peak potential, $E_{p}(\mathrm{mV})$ & Anodic peak potential, $E_{a}(\mathrm{mV})$ & Formal reduction potential, $E_{1 / 2}(\mathrm{mV})$ \\
\hline 50 & $-690 \pm 5$ & $-640 \pm 5$ & $-665 \pm 5$ \\
100 & $-690 \pm 5$ & $-640 \pm 5$ & $-665 \pm 5$ \\
200 & $-690 \pm 5$ & $-640 \pm 5$ & $-665 \pm 5$ \\
300 & $-696 \pm 5$ & $-636 \pm 5$ & $-666 \pm 5$ \\
400 & $-704 \pm 5$ & $-634 \pm 5$ & $-669 \pm 5$ \\
500 & $-706 \pm 5$ & $-630 \pm 5$ & $-668 \pm 5$ \\
600 & $-708 \pm 5$ & $-614 \pm 5$ & $-661 \pm 5$ \\
1000 & $-710 \pm 5$ & $-610 \pm 5$ & $-660 \pm 5$ \\
\hline
\end{tabular}

whether there is any possibility of a chemical reaction along with the electrochemical reduction of the molecule leading to the disappearance of the reduced species, the quinone dianion. For this reason, the cyclic voltammograms at low scan rates failed to show reversible nature. In simulation study (Figure 2), the irreversibility of the electrochemical reaction at lower scan rates was explained by assuming a comproportionation reaction between the quinone dianion (reduced species) and the quinone itself (doxorubicin hydrochloride) forming a semiquinone (Scheme 1). As a result, if more time was provided through the application of lower scan rate, the dianion got sufficient time to react and the concentration of the quinone dianion falls leading to an irreversible reaction. This is in accordance with our previous results where we showed that at alkaline pH sodium 1,4-dihydroxy-9,10-anthraquinone-2-sulphonate, a simple analogue of doxorubicin hydrochloride, undergoes a comproportionation reaction with quinone dianion forming semiquinone [32]. It was observed that in the present study the cathodic peak current $\left(I_{\mathrm{pc}}\right)$ has a linear relationship with the square root of scan rate and passes through the origin (inset of Figure 1) following (1) [33]. This clearly indicates that the reduction was diffusion controlled and there was no adsorption of doxorubicin hydrochloride onto the electrode surface which was also in accordance with previous studies $[31,32]$. Thus it was concluded that the reduction peak current $\left(I_{\mathrm{pc}}\right)$ has a linear relationship with concentration of doxorubicin hydrochloride. Consider

$$
I_{\mathrm{pc}}=0.4463\left(\frac{F^{3}}{\mathrm{RT}}\right)^{1 / 2} n^{3 / 2} A_{0} D_{0}{ }^{1 / 2} C_{0} v^{1 / 2},
$$

where $I_{\mathrm{pc}}, n, A_{0}, D_{0}, C_{0}$, and $v$ refer to the cathodic peak current (A), number of electrons involved in reduction, area of the electrode (in $\left.\mathrm{cm}^{2}\right)$, diffusion coefficient $\left(\mathrm{cm}^{2} \mathrm{~s}^{-1}\right)$, concentration $\left(\mathrm{mol} \mathrm{cm}^{-3}\right)$, and scan rate $\left(\mathrm{Vs}^{-1}\right)$, respectively. Using this relation (see (1)) the diffusion coefficient for the reduction of doxorubicin hydrochloride was determined and it was found to be $3.07 \times 10^{-5} \mathrm{~cm}^{2} \mathrm{~s}^{-1}$. The reduced chi square for the plot (inset of Figure 1) was found to be 0.1135 . mus DNA. Interaction of doxorubicin hydrochloride with

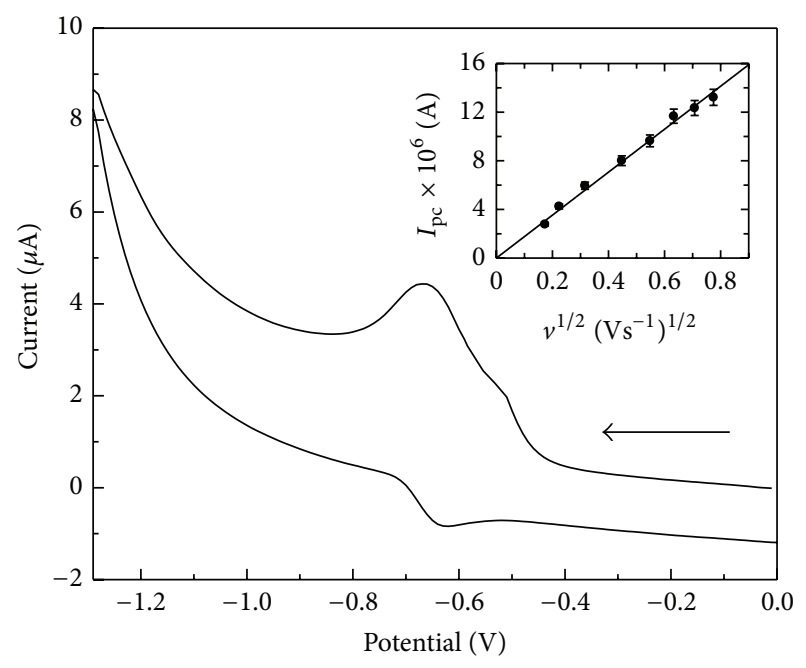

FIGURE 1: Cyclic voltammogram of doxorubicin hydrochloride in aqueous buffer at pH 7.4 on glassy carbon electrode. [Doxorubicin hydrochloride $]=33 \mu \mathrm{M},[\mathrm{NaCl}]=0.160 \mathrm{M}$, scan rate $=0.1 \mathrm{Vs}^{-1}$, and temperature $=25^{\circ} \mathrm{C}$. Inset: plot of cathodic peak current versus square root of scan rate for the two-electron reduction of doxorubicin hydrochloride in aqueous buffer at $\mathrm{pH}$ 7.4.

CT DNA was studied using cyclic voltammetry in aqueous buffer at physiological $\mathrm{pH}$ (7.4) containing $160 \mathrm{mM} \mathrm{NaCl}$. Different solutions were prepared having a fixed concentration $(33 \mu \mathrm{M})$ of doxorubicin hydrochloride and different concentrations of CT DNA. Cyclic voltammetry of each such prepared doxorubicin hydrochloride-CT DNA mixture was carried out and change in cathodic peak current at $-690 \mathrm{mV}$ (versus $\mathrm{Ag} / \mathrm{AgCl}$, saturated $\mathrm{KCl}$ ) was used to construct binding isotherms. Cyclic voltammogram of doxorubicin hydrochloride in the absence and presence of different amounts of CT DNA is shown in Figure 4. Under the same experimental conditions, cyclic voltammetry of pure DNA showed that there was neither any cathodic nor anodic peak in the potential range 0.0 to $-0.85 \mathrm{~V}$, clearly indicating that pure DNA was electrochemically inert in the potential range on a glassy carbon electrode. Previous studies [25, 26, 34, 35] also showed that CT DNA was electrochemically inactive at a glassy carbon electrode surface. 


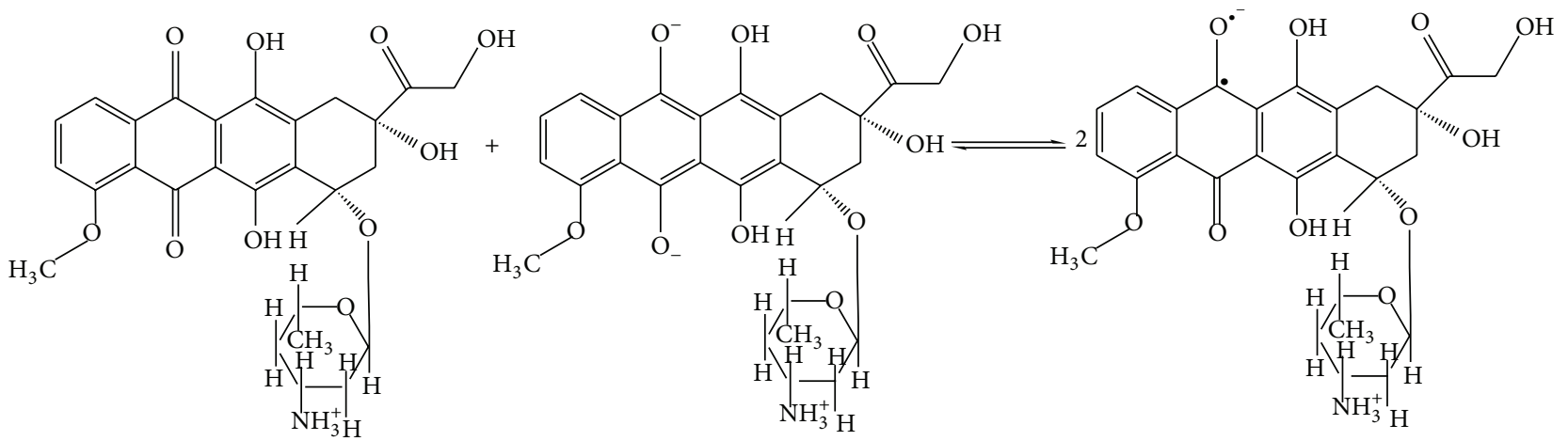

Scheme 1: Comproportionation of doxorubicin hydrochloride dianion and doxorubicin hydrochloride to semiquinone.

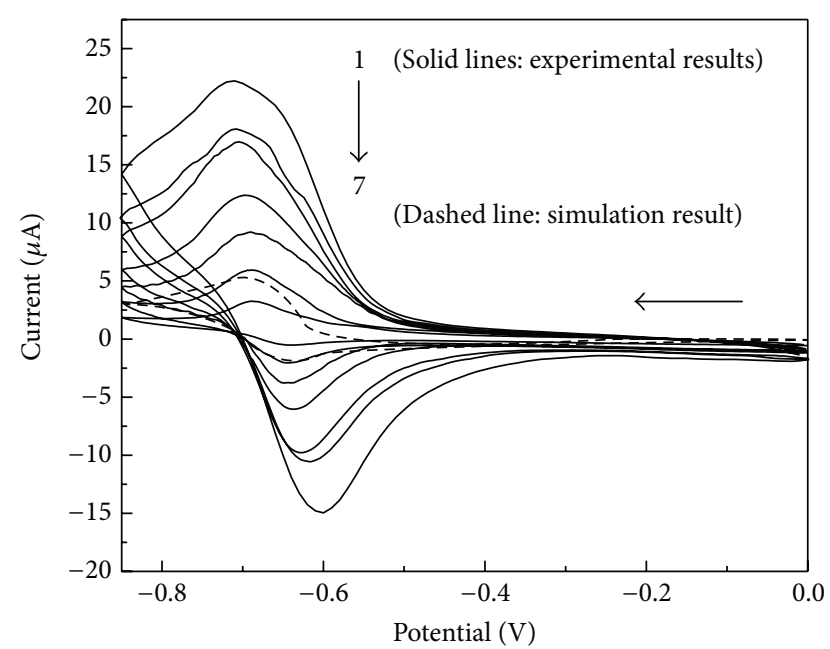

Figure 2: Cyclic voltammograms (solid lines 1-7) of doxorubicin hydrochloride in aqueous buffer at $\mathrm{pH} 7.4$ on glassy carbon electrode. [Doxorubicin hydrochloride] $=33 \mu \mathrm{M}$ and $[\mathrm{NaCl}]=160 \mathrm{mM}$. Scan rates $=1 \mathrm{Vs}^{-1}$ (Curve-1), $0.5 \mathrm{~V} \mathrm{~s}^{-1}$ (Curve-2), $0.4 \mathrm{Vs}^{-1}$ (Curve3), $0.3 \mathrm{Vs}^{-1}$ (Curve-4), 0.2 Vs ${ }^{-1}$ (Curve-5), $0.1 \mathrm{Vs}^{-1}$ (Curve-6), and $0.05 \mathrm{Vs}^{-1}$ (Curve-7), temperature $=25^{\circ} \mathrm{C}$. Dashed line: simulation result. Simulation parameters: $k_{s}=0.03 \mathrm{~cm} \mathrm{~s}^{-1} ; \alpha=0.5 ; E=$ $-0.675 \mathrm{~V}$ (versus $\mathrm{Ag} / \mathrm{AgCl}$, saturated $\mathrm{KCl}, 0.199 \mathrm{~V}$ ) $; D_{0}=3 \times 10^{-5}$, $6.0 \times 10^{-5}, 1.0 \times 10^{-5} \mathrm{~cm}^{2} \mathrm{~s}^{-1}$ for doxorubicin hydrochloride, quinone dianion, and semiquinone, respectively; and electrode area $A=$ $0.1256 \mathrm{~cm}^{2} \cdot k_{f}=10 \times 10^{3}$ and $k_{b}=4 \times 10^{2}$ for the homogeneous chemical reaction (Scheme 1).

To find the reversibility of the reduction of doxorubicin hydrochloride in the presence of DNA, a plot of the ratio of the anodic to cathodic peak current $\left(I_{\mathrm{pa}} / I_{\mathrm{pc}}\right)$ versus the $\operatorname{logarithm}$ of scan rate $(\log v)$ (Figure 3$)$ is considered which shows that the $I_{\mathrm{pa}} / I_{\mathrm{pc}}$ ratio is less than unity for lower scan rates and it is almost unity at higher scan rates [32] clearly suggesting that the reduction is quasireversible at lower scan rates and it is reversible at higher scan rates. However, from Figure 3, it is evident that the reduction of doxorubicin hydrochloride at lower scan rates in the presence of DNA is much more reversible in nature in comparison to that found in the absence of DNA. It is important to note that

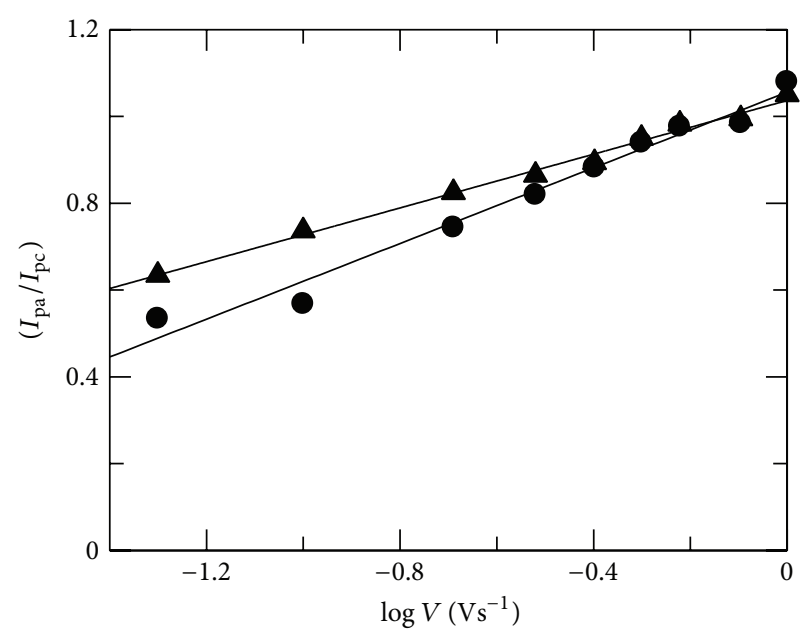

FIGURE 3: Plot of the ratio of anodic to cathodic peak current $\left(I_{\mathrm{pa}} / I_{\mathrm{pc}}\right)$ versus the logarithm of scan rate $(\log v)$ for the reduction of doxorubicin hydrochloride in aqueous buffer at $\mathrm{pH} 7.4$ on glassy carbon electrode in the absence $(\mathbf{)})$ and presence $(\boldsymbol{\Delta})$ of $20 \mu \mathrm{M}$ of CT DNA.

the initial concentration of doxorubicin hydrochloride in the electrochemical experiments in the absence and presence of DNA was the same (i.e., $33 \mu \mathrm{M}$ ). However, owing to the binding of doxorubicin hydrochloride with DNA, the concentration of free doxorubicin hydrochloride molecules (quinone) is significantly reduced in the presence of DNA which means that the chance of the comproportionation reaction between quinone dianion and quinone (Scheme 1) is decreased and as a result the concentration of quinone dianion species is significantly higher in this case. This leads to an increase in the reversibility of the reduction of the compound in the presence of DNA.

With increase in concentration of CT DNA the cathodic peak current for the reduction of doxorubicin hydrochloride decreases (Figure 4). It is necessary to mention that such a decrease in the cathodic peak current was due to interaction of doxorubicin hydrochloride with DNA and not because of any blockage of the electrode surface by an adsorbed layer of DNA. To verify this, cyclic voltammetry of potassium 


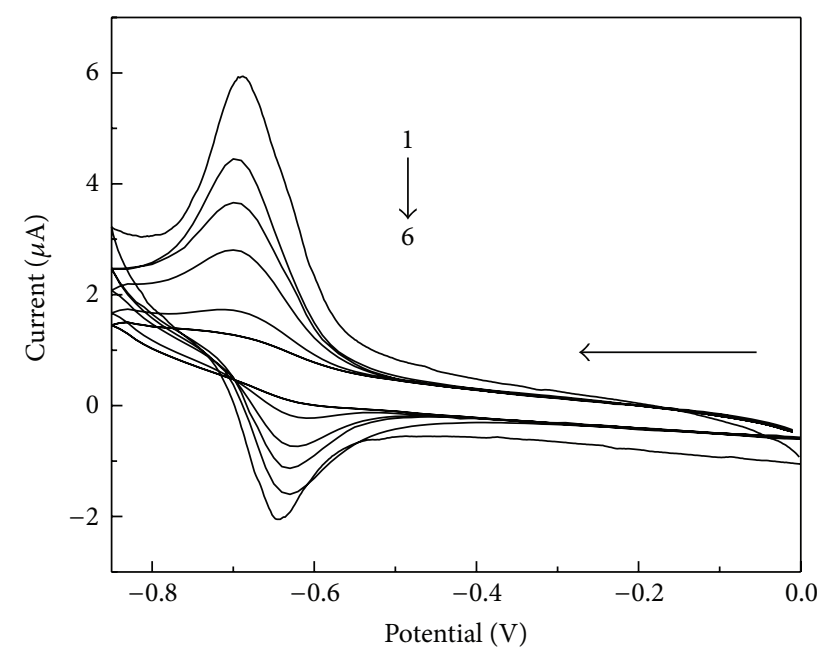

FIGURE 4: Cyclic voltammogram of doxorubicin hydrochloride in the absence (1) and presence of different CT DNA concentrations: $19.9 \mu \mathrm{M}$ (2), $59.31 \mu \mathrm{M}$ (3), $98.2 \mu \mathrm{M}$ (4) $174.47 \mu \mathrm{M}$ (5), and $230.85 \mu \mathrm{M}$ (6). Scan rate $=0.100 \mathrm{Vs}^{-1}, \mathrm{pH}=7.4,[\mathrm{NaCl}]=0.160 \mathrm{M}$, and temperature $=25^{\circ} \mathrm{C}$.

ferricyanide was carried out in the absence and presence of different amounts of CT DNA under similar experimental conditions. It was observed that although the concentration of CT DNA was increased, the cathodic peak current of potassium ferricyanide did not decrease indicating that there was no adsorption of DNA onto the glassy carbon electrode. The fact that in case of the actual experiment doxorubicin hydrochloride interacted with added DNA for which its effective concentration in solution decreased was therefore substantiated. In a previous DNA interaction study, Radi et al. [35] carried out a similar ferricyanide experiment to establish that cyclic voltammetric behavior of their studied compound was not affected by addition of a very large excess of DNA and that decrease in peak current of the compound was due to interaction of the compound with DNA and not owing to adsorption.

Results of DNA titration using cyclic voltammetry were analyzed by the method of nonlinear fitting $[25,26]$. To do so, the following compound-DNA equilibrium was considered [36-39]:

$$
\begin{gathered}
L+D \rightleftharpoons L D \\
K_{d}=\frac{[L][D]}{[L D]}=\frac{\left\{\left[L_{0}\right]-[L D]\right\}\left\{\left[D_{0}\right]-[L D]\right\}}{L D},
\end{gathered}
$$

where $L$ represents doxorubicin hydrochloride, $D$ represents CT DNA, and $L D$ represents the doxorubicin hydrochlorideDNA adduct. The dissociation constant $\left(K_{d}\right)=1 / K, K$ being apparent binding constant of the compound to DNA. $\left[L_{0}\right]=$ initial concentration of doxorubicin hydrochloride $=$ [doxorubicin hydrochloride $]_{0}=33 \mu \mathrm{M}$ (which was kept constant during the titration experiment). $\left[D_{0}\right]=[\mathrm{DNA}]$ $=$ concentration of DNA added to an aliquot. If $C_{0}$ is the initial concentration of doxorubicin hydrochloride, that is,
$C_{0}=\left[L_{0}\right]=[\text { doxorubicin hydrochloride }]_{0}$ and $C_{D}=\left[D_{0}\right]=$ $[D N A]=$ the concentration of DNA added to an aliquot, then

$$
K_{d}=\frac{\left\{C_{0}-[L D]\right\}\left\{C_{D}-[L D]\right\}}{[L D]} .
$$

Studies carried out earlier already established the fact that the 9,10-anthraquinone unit of anthracyclines binds to DNA by intercalation owing to its planar hydrophobic structure $[40,41]$ and that doxorubicin hydrochloride-DNA adduct was not electroactive $[11,34]$. Since there was no interference from doxorubicin hydrochloride-DNA adduct [34], the cathodic peak current $\left(I_{\mathrm{pc}}\right)$ was linearly proportional to the concentration of free, that is, nonbound, doxorubicin hydrochloride (see (1)). Using this linear relationship between cathodic peak current and concentration of doxorubicin hydrochloride and applying the same analogy one applies for absorption and fluorescence, the following parameters were defined [36-39].

$\Delta I=\left(I_{\mathrm{pc}}{ }^{0}-I_{\mathrm{pc}}\right)=$ change in cathodic peak current $\left(I_{\mathrm{pc}}\right)$ of doxorubicin hydrochloride at $-690 \mathrm{mV}$ (versus $\mathrm{Ag} / \mathrm{AgCl}$, saturated $\mathrm{KCl}$ ) upon each addition of CT DNA for each point of the titration. $I_{\mathrm{pc}}{ }^{0}$ and $I_{\mathrm{pc}}$ are cathodic peak current of doxorubicin hydrochloride at $-690 \mathrm{mV}$ (versus $\mathrm{Ag} / \mathrm{AgCl}$, saturated $\mathrm{KCl}$ ) in the absence and presence of different amounts of CT DNA, respectively. $\Delta I_{\max }$ is the same parameter when doxorubicin hydrochloride was totally bound to CT DNA. Therefore, $\left(\Delta I / \Delta I_{\max }\right)$ denotes the fraction of doxorubicin hydrochloride bound to DNA and one gets $\left(\Delta I / \Delta I_{\max }\right) \mathrm{C}_{0}$ $=[L D]=[$ DNA-doxorubicin hydrochloride $]$. Therefore, it can be said that, at any point of the titration, cathodic peak current was due to the contribution of free doxorubicin hydrochloride only. Putting the value of $[L D]$ in (3), one gets

$$
\begin{gathered}
K_{d}=\frac{\left[C_{0}-\left(\Delta I / \Delta I_{\max }\right) C_{0}\right]\left[C_{D}-\left(\Delta I / \Delta I_{\max }\right) C_{0}\right]}{\left(\Delta I / \Delta I_{\max }\right) C_{0}}, \\
C_{0}\left(\frac{\Delta I}{\Delta I_{\max }}\right)^{2}-\left(C_{0}+C_{D}+K_{d}\right)\left(\frac{\Delta I}{\Delta I_{\max }}\right)+C_{D}=0 .
\end{gathered}
$$

Determination of $K_{d}$ using (5) requires the value of $\Delta I_{\max }$ which was determined by double reciprocal plot (Figure 5) using $[25,26]$

$$
\frac{1}{\Delta I}=\frac{1}{\Delta I_{\max }}+\frac{K_{d}}{\Delta I_{\max }\left(C_{D}-C_{0}\right)} .
$$

This double reciprocal plot (Figure 5) was also used to determine the apparent dissociation constant $\left(K_{d}\right)$ that was also determined using nonlinear curve fit analysis using (5). The apparent binding constant $\left(K_{\text {app }}=1 / K_{d}\right)$ obtained from the double reciprocal plot (see (6), Figure 5) was found to be $(1.66 \pm 0.12) \times 10^{4} \mathrm{M}^{-1}$. The correlation coefficient for this plot was observed to be 0.00037 . The parameters are summarized in Table 2.

All the experimental points in the binding isotherms were fitted by least-square analysis. The basic assumption was that the concentration of doxorubicin hydrochloride was $33 \mu \mathrm{M}$ (kept constant during titration). CT DNA concentration was 10 -fold greater than doxorubicin hydrochloride. 
TABLE 2: Evaluated electrochemical parameters, binding parameters, reduced chi square, and correlation coefficient for the plots.

\begin{tabular}{|c|c|c|c|c|c|c|c|c|}
\hline \multicolumn{2}{|c|}{ Diffusion coefficient } & \multicolumn{2}{|c|}{ Double reciprocal plot } & \multicolumn{2}{|c|}{ Nonlinear fit } & \multicolumn{2}{|c|}{ Binding site size } & \multirow[b]{2}{*}{$\begin{array}{l}\text { Intrinsic binding } \\
\text { constant } K^{\prime} \\
\left(\mathrm{M}^{-1}\right)\end{array}$} \\
\hline $\begin{array}{l}D_{0} \\
\left(\mathrm{~cm}^{2} \mathrm{~s}^{-1}\right)\end{array}$ & $\begin{array}{l}\text { Reduced chi } \\
\text { square for the } \\
\text { plot }\end{array}$ & $K_{\text {app }}\left(\mathrm{M}^{-1}\right)$ & $\begin{array}{l}\text { Correlation } \\
\text { coefficient for } \\
\text { the plot }\end{array}$ & $K_{\text {app }}\left(\mathrm{M}^{-1}\right)$ & $\begin{array}{l}\text { Correlation } \\
\text { coefficient for } \\
\text { the plot }\end{array}$ & $n$ (bases) & $\begin{array}{l}\text { Reduced chi } \\
\text { squares for } \\
\text { the plot }\end{array}$ & \\
\hline $3.07 \times 10^{-5}$ & 0.1135 & $(1.66 \pm 0.12) \times 10^{4}$ & 0.00037 & $(1.81 \pm 0.15) \times 10^{4}$ & 0.0022 & $5.80 \pm 0.40$ & $\begin{array}{c}0.9849 \text { and } \\
0.8914\end{array}$ & $(1.05 \pm 0.10) \times 10^{5}$ \\
\hline
\end{tabular}

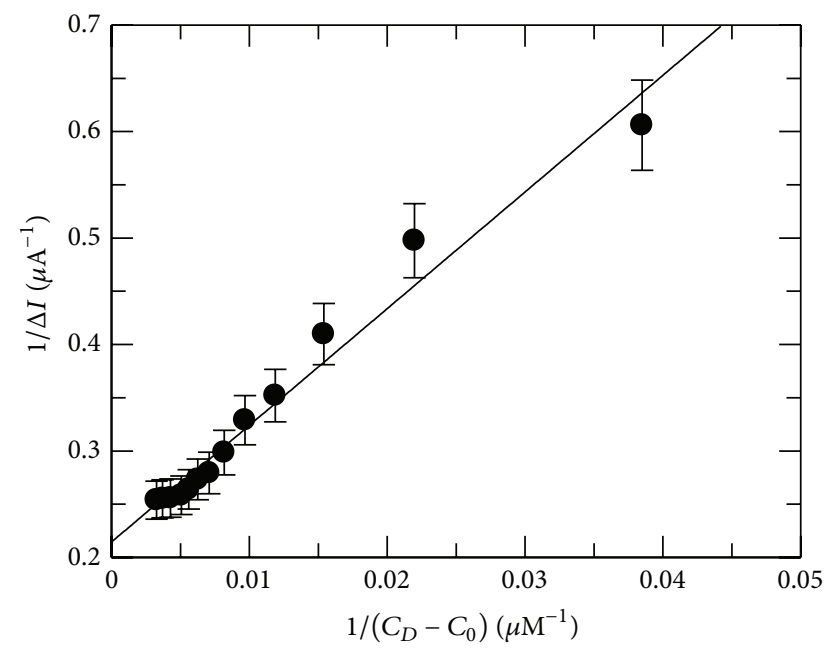

FIGURE 5: Double reciprocal plot of doxorubicin hydrochlorideCT DNA interaction using cyclic voltammetry; [doxorubicin hydrochloride $]=33 \mu \mathrm{M}, \mathrm{pH}=7.4,[\mathrm{NaCl}]=0.160 \mathrm{M}$, and temperature $=25^{\circ} \mathrm{C}$.

Binding stoichiometry or binding site size was determined from the point of intersection of two straight lines obtained from the least-square fit plot of normalized increase of $\Delta I / \Delta I_{\max }$ against ratio of concentrations of CT DNA (in base) to doxorubicin hydrochloride $[25,26]$ that was drawn considering points before and after saturation, respectively $[25,26]$. The point of intersection of the two straight lines indicates a ratio of the moles of DNA (in bases) to the mole of doxorubicin hydrochloride in which the saturation is just reached, that is, the number of DNA bases bound per doxorubicin hydrochloride. Figure 6 shows the binding isotherm of doxorubicin hydrochloride and CT DNA. The correlation coefficient for this plot was observed as 0.0022 which is a measure of the extent to which the fitted line matches with the experimental data points. The apparent binding constant $\left(K_{\mathrm{app}}=1 / K_{d}\right)$ was calculated using (5) as described above and obtained as $(1.81 \pm 0.15) \times 10^{4} \mathrm{M}^{-1}$ (Table 2$)$. The apparent binding constant obtained from double reciprocal plot (see (6), Figure 5) was $(1.66 \pm 0.12) \times 10^{4} \mathrm{M}^{-1}$ (Table 2) indicating that there was excellent agreement between the two approaches. A previous study by Hajian and coworkers [42] showed apparent binding constant for the interaction of doxorubicin hydrochloride-CT DNA in phosphate buffer at $\mathrm{pH} 7.4$ as $(3.2 \pm 0.24) \times 10^{4} \mathrm{M}^{-1}$ which was also in good

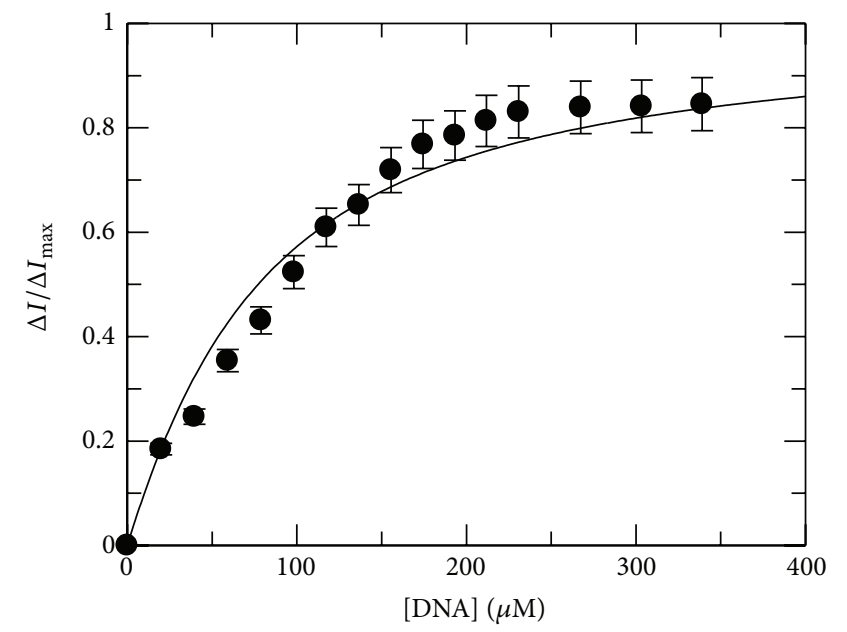

FIgURE 6: Binding isotherm of doxorubicin hydrochloride-CT DNA interaction and corresponding nonlinear fit using cyclic voltammetry; [doxorubicin hydrochloride] $=33 \mu \mathrm{M}, \mathrm{pH}=7.4$, $[\mathrm{NaCl}]=0.160 \mathrm{M}$, and temperature $=25^{\circ} \mathrm{C}$.

agreement with our results. The slight deviation between the previous and present results may be due to different types of measurements and different reaction media in the two studies. Figure 7 shows the plot of normalized increase of $\Delta I / \Delta I_{\max }$ as a function of mole ratio of DNA to doxorubicin hydrochloride and provides the value for the binding site size $(n)=5.80 \pm 0.40$ bases, that is, $2.90 \pm 0.20$ base pairs per molecule of doxorubicin hydrochloride (Table 2). The reduced chi square values for the plot of straight lines (Figure 7) before and after the saturation were found to be 0.9849 and 0.8914 , respectively, which are the measure of compatibility of fitting of the experimental results with the appropriate equation. Knowing $n$, the intrinsic binding constant $K^{\prime}$, that is, $(K \times n)$, was obtained as (1.05 \pm $0.10) \times 10^{5} \mathrm{M}^{-1}$ (Table 2 ). A previous study had reported intrinsic binding constant for the interaction of doxorubicin hydrochloride with CT DNA as $2.7 \times 10^{5} \mathrm{M}^{-1}$ at $\mathrm{pH} 7.4$ [43] and binding site size as $3.1 \pm 0.4$ base pairs per drug molecule [44]. Thus previous results also justify ours and the methods of measurements.

\section{Conclusion}

Doxorubicin hydrochloride undergoes two-electron reversible reduction generating a cathodic peak at $-690 \pm 5 \mathrm{mV}$ (versus $\mathrm{Ag} / \mathrm{AgCl}$, saturated $\mathrm{KCl}$ ) with 


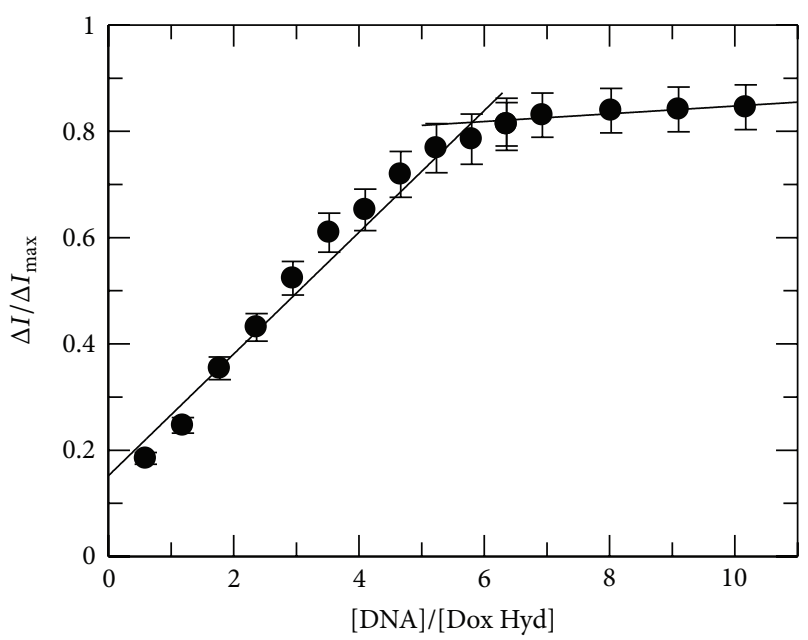

FIGURE 7: Plot of normalized increase of cathodic peak current as a function of mole ratio of CT DNA to doxorubicin hydrochloride.

a corresponding anodic peak at $-640 \pm 5 \mathrm{mV}$ (versus $\mathrm{Ag} / \mathrm{AgCl}$, saturated $\mathrm{KCl}$ ) at $\mathrm{pH}$ 7.4. The formal reduction potential $\left(E_{1 / 2}\right)$ was found to be $-665 \pm 5 \mathrm{mV}$ (versus $\mathrm{Ag} / \mathrm{AgCl}$, saturated $\mathrm{KCl}$ ). The reduced species undergoes comproportionation with the neutral molecule to form semiquinone leading to irreversible reduction at lower scan rate established by simulation. Cathodic peak current for doxorubicin hydrochloride decreased as calf thymus DNA was gradually increased in solutions containing a fixed concentration of doxorubicin hydrochloride. The decrease in peak current was used to evaluate binding parameters for the interaction of the drug to CTDNA. Intrinsic binding constant and bind site size were $(1.05 \pm 0.10) \times 10^{5} \mathrm{M}^{-1}$ and $2.90 \pm 0.20$ base pairs of DNA per molecule of doxorubicin hydrochloride, respectively. Our results support earlier data.

\section{Abbreviation}

CT DNA: Calf thymus DNA.

\section{Conflict of Interests}

The authors declare that there is no conflict of interests regarding the publication of this paper.

\section{Acknowledgments}

P. S. Guin is grateful to the University Grants Commission, New Delhi, India, for funding the major research project (F. no. 41-225/2012 (SR) dated July 18, 2012). S. Das gratefully acknowledges the financial support from DST, Government of West Bengal [794(Sanc.)1(10) ST/P/S\&T/9G-23/2013] provided in the form of a research project.

\section{References}

[1] R. Ng, N. Better, and M. D. Green, "Anticancer agents and cardiotoxicity," Seminars in Oncology, vol. 33, no. 1, pp. 2-14, 2006.
[2] G. Minotti, P. Menna, E. Salvatorelli, G. Cairo, and L. Gianni, "Anthracyclines: molecular advances and pharmacologie developments in antitumor activity and cardiotoxicity," Pharmacological Reviews, vol. 56, no. 2, pp. 185-229, 2004.

[3] F. Arcamone, Doxorubicin, Anticancer Antibiotic, Academic Press, New York, NY, USA, 1981.

[4] V. Behal, "Bioactive products from Streptomyces," Advances in Applied Microbiology, vol. 47, pp. 113-156, 2000.

[5] C. E. Myers, E. G. Mimnaugh, G. C. Yeh, and B. K. Sinha, "Biochemical mechanisms of tumor cell kill by the anthracyclines," in Anthracycline and Anthracenedione-Based Anticancer Agents, J. W. Lown, Ed., pp. 527-569, Elsevier, Amsterdam, The Netherlands, 1988.

[6] L. Gianni, B. Corden, and C. E. Myers, "The biochemical bases of anthracycline toxicity and antitumor action," in Reviews in Biochemical Toxicology, E. Hodgson, J. R. Bend, and R. M. Philipot, Eds., vol. 5, pp. 1-82, Elsevier, Amsterdam, The Netherlands, 1983.

[7] S. E. Lipshultz, "Exposure to anthracyclines during childhood causes cardiac injury," Seminars in Oncology, vol. 33, no. 8, pp. S8-S14, 2006.

[8] M. Binaschi, G. Capranico, L. Dal Bo, and F. Zunino, "Relationship between lethal effects and topoisomerase II-mediated double-stranded DNA breaks produced by anthracyclines with different sequence specificity," Molecular Pharmacology, vol. 51, no. 6, pp. 1053-1059, 1997.

[9] D. A. Gewirtz, "A critical evaluation of the mechanisms of action proposed for the antitumor effects of the anthracycline antibiotics adriamycin and daunorubicin," Biochemical Pharmacology, vol. 57, no. 7, pp. 727-741, 1999.

[10] G. E. Kellogg, J. N. Scarsdale, and F. A. Fornari Jr., "Identification and hydropathic characterization of structural features affecting sequence specificity for doxorubicin intercalation into DNA double-stranded polynucleotides," Nucleic Acids Research, vol. 26, no. 20, pp. 4721-4732, 1998.

[11] H. M. Zhang and N. Q. Li, "Electrochemical studies of the interaction of adriamycin to DNA," Journal of Pharmaceutical and Biomedical Analysis, vol. 22, no. 1, pp. 67-73, 2000.

[12] J. B. Chaires, "Molecular recognition of DNA," in Advances in DNA Sequence-Specific Agents, L. H. Hurley and J. B. Chaires, Eds., vol. 2, pp. 141-167, CT: JAI Press, Greenwich, UK, 1996.

[13] A. H.-J. Wang, "Structure-activity studies of anthracyclineDNA complexe," in Molecular Aspects of Anticancer Drug-DNA Interactions, S. Neidle and M. Waring, Eds., vol. 1, pp. 32-53, CRC Press, Boca Raton, Fla, USA, 1993.

[14] K. Studzian, M. Wasowska, M. K. Piestrzeniewicz et al., "Inhibition of RNA synthesis in vitro and cell growth by anthracycline antibiotics," Neoplasma, vol. 48, no. 5, pp. 412-418, 2001.

[15] F. Leng and G. H. Leno, "Daunomycin disrupts nuclear assembly and the coordinate initiation of DNA replication in Xenopus egg extracts," Journal of Cellular Biochemistry, vol. 64, pp. 476491, 1997.

[16] M. Gigli, S. M. Doglia, J. M. Millot, L. Valentini, and M. Manfait, "Quantitative study of doxorubicin in living cell nuclei by microspectrofluorometry," Biochimica et Biophysica Acta, vol. 950, no. 1, pp. 13-20, 1988.

[17] F. Belloc, F. Lacombe, P. Dumain et al., "Intercalation of anthracyclines into living cell DNA analyzed by flow cytometry," Cytometry, vol. 13, no. 8, pp. 880-885, 1992.

[18] K. E. van Holde, Chromatin, Springer, New York, NY, USA, 1988. 
[19] A. Rabbani, M. Iskandar, and J. Ausió, "Daunomycin-induced unfolding and aggregation of chromatin," The Journal of Biological Chemistry, vol. 274, no. 26, pp. 18401-18406, 1999.

[20] T. Lee, T. Lau, and I. Ng, "Doxorubicin-induced apoptosis and chemosensitivity in hepatoma cell lines," Cancer Chemotherapy and Pharmacology, vol. 49, no. 1, pp. 78-86, 2002.

[21] R. Abraham, R. L. Basser, and M. D. Green, "A risk-benefit assessment of anthracycline antibiotics in amtineoplastic therapy," Drug Safety, vol. 15, no. 6, pp. 406-429, 1996.

[22] G. P. Stathopoulos, N. A. Malamos, I. Dontas, G. Deliconstantinos, D. Perrea-Kotsareli, and P. E. Karayannacos, "Inhibition of adriamycin cardiotoxicity by 5 -fluorouracil: a potential free oxygen radical scavenger," Anticancer Research, vol. 18, no. 6, pp. 4387-4392, 1998.

[23] G. Falcone, W. Filippelli, B. Mazzarella et al., "Cardiotoxicity of doxorubicin: effects of 21-aminosteroids," Life Sciences, vol. 63, no. 17, pp. 1525-1532, 1998.

[24] G. F. Samelis, G. P. Stathopoulos, D. Kotsarelis, I. Dontas, C. Frangia, and P. E. Karayannacos, "Doxorubicin cardiotoxicity and serum lipid increase is prevented by dextrazoxane (ICRF187)," Anticancer Research, vol. 18, pp. 3305-3309, 1998.

[25] P. S. Guin and P. C. Mandal, "Electrochemistry and VIS spectroscopy on the binding of sodium 1, 4-dihydroxy-9, 10anthraquinone-2-sulphonate- $\mathrm{Cu}(\mathrm{II})$ complex to calf thymus DNA," ChemPlusChem, vol. 77, pp. 361-389, 2012.

[26] P. S. Guin, P. Das, S. Das, and P. C. Mandal, "Interaction of calf thymus DNA with the Ni(II) complex of sodium 1,4dihydroxy-9,10-anthraquinone-2-sulphonate: a novel method of analysis using cyclic voltammetry," International Journal of Electrochemistry, vol. 2012, Article ID 183745, 10 pages, 2012.

[27] O. Warburg and W. Christian, "Isolation and crystallization of enolase," Biochemische Zeitschrift, vol. 310, pp. 384-421, 1942.

[28] T. Ossowski, P. Pipka, A. Liwo, and D. Jeziorek, "Electrochemical and UV-spectrophotometric study of oxygen and superoxide anion radical interaction with anthraquinone derivatives and their radical anions," Electrochimica Acta, vol. 45, no. 21, pp. 3581-3587, 2000.

[29] G. M. Rao, J. W. Lown, and J. A. Plambeck, "Electrochemical studies of antitumor antibiotics: daunorubicin and adriamycin," Journal of the Electrochemical Society, vol. 125, no. 4, pp. 534539, 1978.

[30] C. Molinier-Jumel, B. Malfoy, J. A. Reynaud, and G. AubelSadron, "Electrochemical study of DNA-anthracyclines interaction," Biochemical and Biophysical Research Communications, vol. 84, no. 2, pp. 441-449, 1978.

[31] K. Kano, T. Konse, N. Nishimura, and T. Kubota, "Electrochemical properties of adriamycin adsorbed on a mercury electrode surface," Bulletin of the Chemical Society of Japan, vol. 57, no. 9, pp. 2383-2390, 1984.

[32] P. S. Guin, S. Das, and P. C. Mandal, "Electrochemical Reduction of Sodium 1, 4-dihydroxy-9, 10-anthraquinone-2-sulphonate in Aqueous and aqueous dimethyl formamide mixed solvent: a cyclic voltammetric study," International Journal of Electrochemical Science, vol. 3, pp. 1016-1028, 2008.

[33] A. J. Bard and L. R. Faulkner, Electrochemical Methods: Fundamentals and Applications, John Wiley \& Sons, 2001.

[34] J. B. Hu, J. Shang, and Q. L. Li, "Electrochemical studies of adriamycin interaction with DNA and determination of DNA at a NI/GC ion implantation modified electrode," Analytical Letters, vol. 33, no. 9, pp. 1843-1855, 2000.
[35] A. Radi, M. A. El Ries, and S. Kandil, "Electrochemical study of the interaction of levofloxacin with DNA," Analytica Chimica Acta, vol. 495, no. 1-2, pp. 61-67, 2003.

[36] P. S. Guin, S. Das, and P. C. Mandal, "Studies on the formation of a complex of $\mathrm{Cu}(\mathrm{II})$ with sodium 1,4-dihydroxy-9,10anthraquinone-2-sulphonate-an analogue of the core unit of anthracycline anticancer drugs and its interaction with calf thymus DNA," Journal of Inorganic Biochemistry, vol. 103, no. 12, pp. 1702-1710, 2009.

[37] P. S. Guin, S. Das, and P. C. Mandal, "Sodium 1, 4-dihydroxy9, 10-anthraquinone- 2-sulphonate interacts with calf thymus DNA in a way that mimics anthracycline antibiotics: an electrochemical and spectroscopic study," Journal of Physical Organic Chemistry, vol. 23, no. 6, pp. 477-482, 2010.

[38] P. S. Guin, S. Das, and P. C. Mandal, "Interaction of 1,4dihydroxy-9,10-anthraquinone with Calf thymus DNA: a comparison with anthracycline anticancer drugs," Journal of Solution Chemistry, vol. 40, no. 3, pp. 492-501, 2011.

[39] P. Das, P. S. Guin, P. C. Mandal, M. Paul, S. Paul, and S. Das, "Cyclic voltammetric studies of 1,2,4-trihydroxy-9,10anthraquinone, its interaction with calf thymus DNA and antileukemic activity on MOLT-4 cell lines: a comparison with anthracycline anticancer drugs," Journal of Physical Organic Chemistry, vol. 24, no. 9, pp. 774-785, 2011.

[40] W. Y. Li, J. G. Xu, X. Q. Guo, Q. Z. Zhu, and Y. B. Zhao, "Determination of DNA by use of in situ photochemical fluorescence probe sodium 9,10-anthraquinone-2-sulfonate as a photochemical fluorescence probe," Chemical Journal of Chinese Universities, vol. 17, no. 11, pp. 1706-1707, 1996.

[41] Z. Zhu and N. Q. Li, "Electrochemical studies of the interaction of 9,10-anthraquinone with DNA," Microchemical Journal, vol. 59, no. 2, pp. 294-306, 1998.

[42] R. Hajian, N. Shams, and M. Mohagheghian, "Study on the interaction between doxorubicin and deoxyribonucleic acid with the use of methylene blue as a probe," Journal of the Brazilian Chemical Society, vol. 20, no. 8, pp. 1399-1405, 2009.

[43] F. Frezard and A. Garnier-Suillerot, "Comparison of the binding of anthracycline derivatives to purified DNA and to cell nuclei," Biochimica et Biophysica Acta, vol. 1036, no. 2, pp. 121-127, 1990.

[44] F. Barcelo, J. Martorell, F. Gavilanes, and J. M. Gonzalez-Ros, "Equilibrium binding of daunomycin and adriamycin to calf thymus DNA. Temperature and ionic strength dependence of thermodynamic parameters," Biochemical Pharmacology, vol. 37, no. 11, pp. 2133-2138, 1988. 

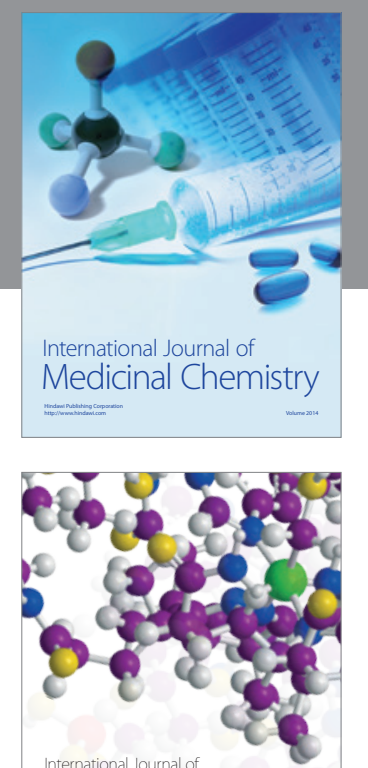

\section{Carbohydrate} Chemistry

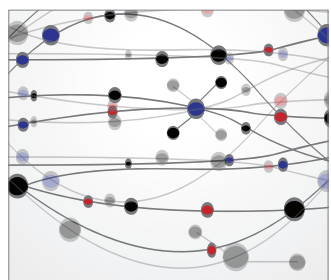

The Scientific World Journal
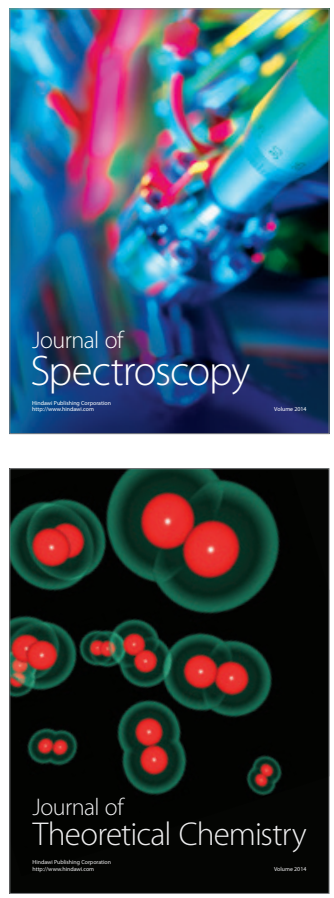
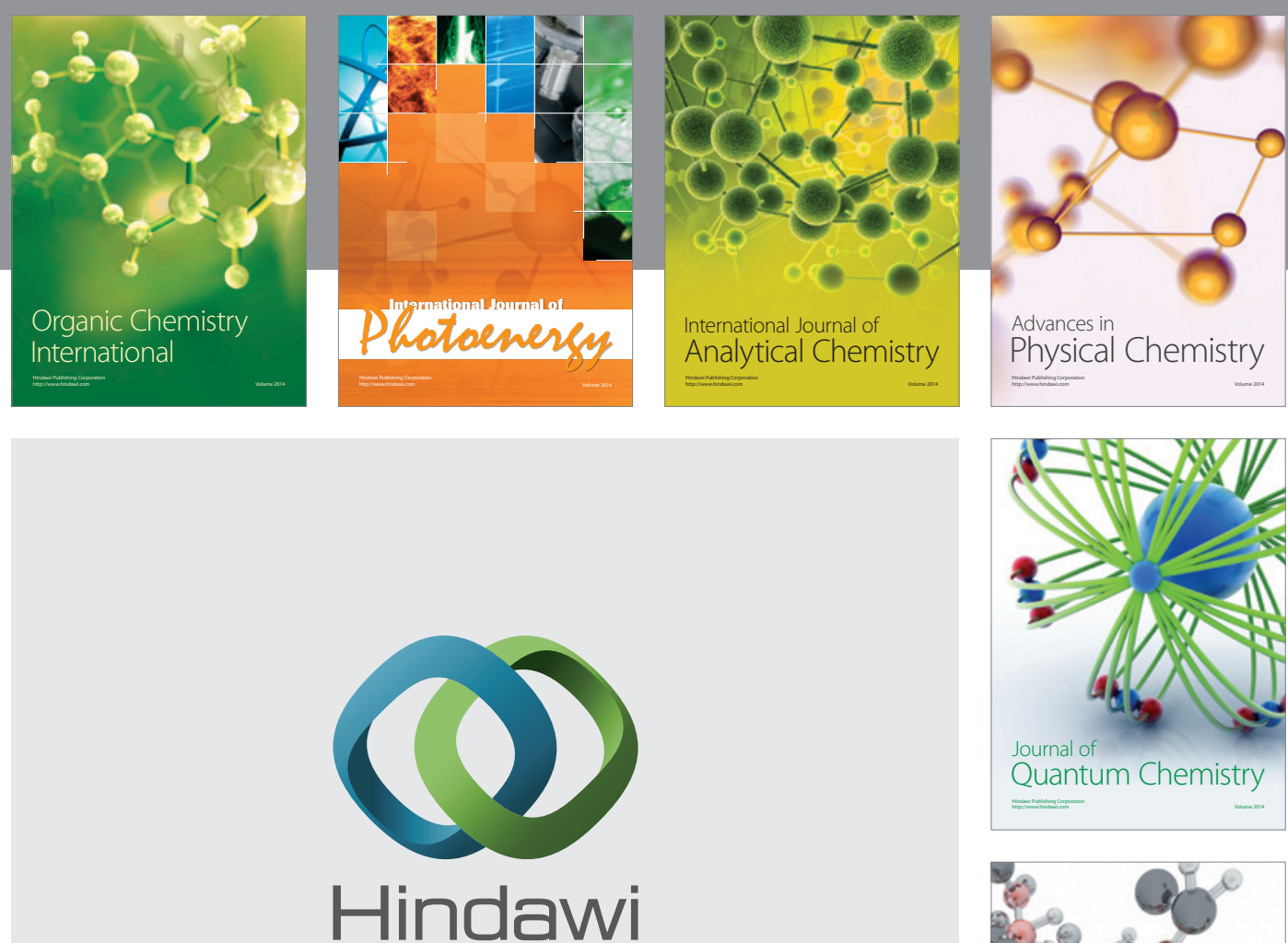

Submit your manuscripts at

http://www.hindawi.com

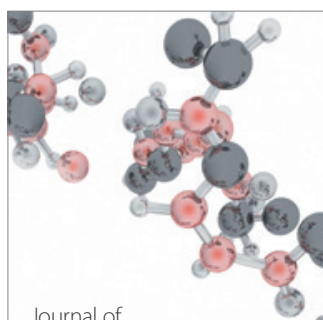

Analytical Methods

in Chemistry

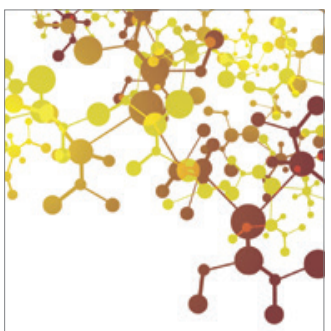

Journal of

Applied Chemistry

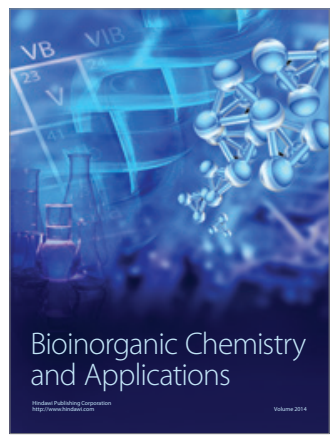

Inorganic Chemistry
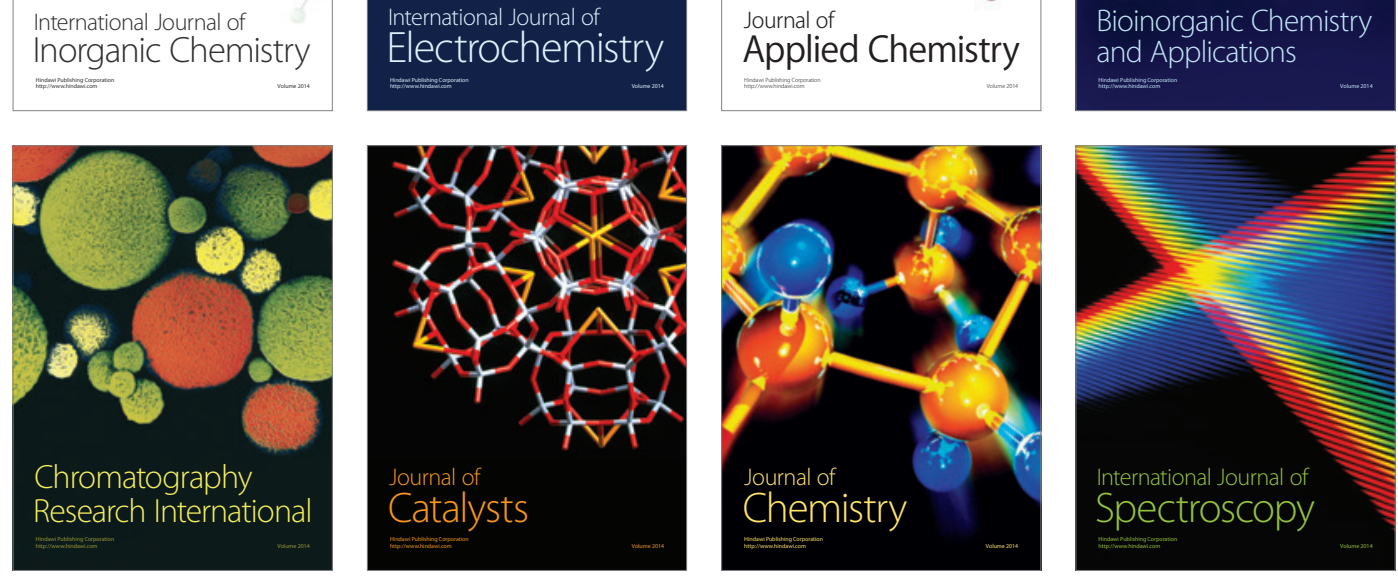